\title{
Etik Liderlik ve Örgütsel Vatandaşlık Davranışı İlişkisinde Örgütsel Özdeşleşmenin Aracılık Etkisi ve Bir Uygulama
}

\author{
Deniz PALALAR ALKAN* F. Şebnem ARIKBOĞA**
}

\begin{abstract}
$\ddot{O} Z$
Bu çalışmanın amacı etik liderlik, örgütsel özdeşleşme ve örgütsel vatandaşlık davranışı (ÖVD) arasındaki ilişkiyi incelemektir. Çalışmada, 15 Aralık 2014 ile 15 Mart 2015 tarihleri arasında Türkiye Bankalar Birliği'ne üye İstanbul ilinde faaliyet gösteren mevduat bankalarındaki 424 banka çalışanından toplanan veriler kullanılmıştır. Bu bağlamda banka yöneticilerinin etik lider davranışlarına ilişkin algıları belirlenmiş, etik lider davranışlarının örgütsel özdeşleşme üzerine etkisi araştırılmış ve örgütsel özdeşleşmenin de ÖVD üzerindeki etkisi ortaya konmuştur. Bulgular, yöneticilerini etik lider olarak değerlendiren çalışanların örgütleri ile daha güçlü özdeşleştiğini ve bu "bir" olma duygusunun ÖVD'yi olumlu yönde etkilediğini göstermiştir.
\end{abstract}

Anahtar Kelimeler: Etik Liderlik, Örgütsel Vatandaşlık Davranışı, Örgütsel Özdeşleşme.

JEL Sinıflandırmast: $M 1$

\section{A Study Investigating The Mediating Role of Organizational Identification between Ethical Leadership and Organizational Citizenship Behavior}

\section{ABSTRACT}

The aim of this study is to find out the relationship between ethical leadership, organizational identification and organizational citizenship behavior (OCB). For the purpose of this study, data collected from 424 employees who work at the depository banks in Istanbul which are members of the Banks Association of Turkey between the dates of December 152014 and March 15 2015. In this context, the perception towards bank managers ethical leaderhsip behaviors were determined, the effect of ethical leadership behavior on organizational identification was investigated and the impact of organizational identification on OCB was determined. The results demonstrated that employees who assess their manager as an ethical leader shows stronger identification with the organization and this "oneness" have a positive effect on OCB.

Key Words: Ethical Leadership, Organizational Citizenship Behaviour, Organizational Identification.

JEL Classification: $M 1$

\section{GİRIŞ}

Son çeyrek yüzyıl içerisinde yaşanılan, yansımaları geniş bir çerçevede etki yaratan skandallar, etkileri ve sonuçları nedeniyle pek çok alanda gündemi meşgul etmektedir. Özellikle finans ve bankacılık sektöründe yaşanan etik

\footnotetext{
* Yrd.Doç.Dr. Deniz Palalar AlkanHaliç Üniversitesi İşletme Fakültesi İngilizce İşletme Bölümü, denizpalalar@halic.edu.tr.

** Prof.Dr. F. Şebnem Arıkboğa, İstanbul Üniversitesi, İktisat Fakültesi İşletme Bölümü, sebnema@istanbul.edu.tr
} 
skandalların etkileri (referans verebilir misiniz) göz önüne alındığında önemli bir sorunsal ile karşı karşıya kalındığı görülmektedir. Küresel boyutta yaşanan sosyal ve ekonomik krizler, liderlerin ve çalışanların yönetsel kararlarda etik değerlerden saptıklarını ortaya koymakla beraber söz konusu değerlerin yönetsel alandaki önemi daha da belirgin hale gelmektedir. Böylece liderlik yaklaşımlarında yıllardır arka plana itilen etik olgusunu temele alan bir liderlik anlayışına olan ihtiyacı ön plana çıkarmaktadır.

Liderin vizyonu ve taşıdığı değerler, örgütün maddi-manevi varlığını şekillendirirken, iş görenlere rehberlik ederek rol model olmaktadır. Liderin sahip olduğu gücün kullanımı ve verdiği kararları sadece örgütü değil tüm paydaşları etkilemektedir. $\mathrm{Bu}$ nedenle liderin verdiği kararların belirli evrensel kurallar temelinde inşa edilmesini gerekli kılmaktadır (özne yüklem uyumu yok). Lider rol model oluşturarak belirli etik değerlerin içselleştirilmesini sağlamakta; bireylerin tutum ve davranışlarına etki etmektedir. Dolayısıyla bireysel farklılıkları ortadan kaldıran; adil yaklaşım, dürüstlük, tarafsızlık gibi evrensel değerleri benimseyen; çalışanların örgütleri ile özdeşleşmelerini; sahip olduğu karar gücünü paylaşmaya dayanan lider davranışları örgütsel başarının kilit faktörü olarak görülmektedir.

Küreselleşmenin etkileri ile birlikte yönetsel alanda yaşanılan radikal değişimler, işletmelerin merkezine insan unsurunu yerleştirmiştir. Uzun dönemli karlılığın ön plana çıktığı; çalışan ve müşteri ihtiyaçları ile beraber tüm toplum çıkarlarının dengelenmesi gerekliliği yeni liderlik çalışmalarına yön vermektedir. Bununla birlikte son dönemde yaşanılan küresel krizler ve bu krizlerin tüm örgüt paydaşlarına olan etkileri değerlendirildiğinde, etik değerleri merkezileştiren etik liderlik önem kazanmaktadır. Etik lider davranışlarının çalışanların örgütlerine yönelik olumlu tutum sergilemelerine yol açtığı, ilişkin literatür ile desteklenmektedir. Bu olumlu tutum ve davranışlara bireylerin örgütleri ile 'bir' olma duygularını ifade eden örgütsel özdeşleşme ile biçimsel rol ötesi davranışlar şeklinde nitelendirilen örgütsel vatandaşlık davranışı örnek teşkil etmektedir. Bu kapsamda, çalışmada etik lider davranışlarının, iş görenlerin örgütsel özdeşleşmeleri ve örgütsel vatandaşlık davranışı sergilemeleri üzerindeki etkisinin çıkarılması amaçlanmıştır.

\section{ETİK LIDDERLİK}

Sosyal bir varlık olarak insan, birlikte yaşamanın getirdiği faydalar sebebi ile tarih boyunca topluluk halinde yaşama eğilimi sergilemektedir. Yönetimin bir bilim olarak ele alındığı klasik yönetim anlayışından günümüz modern toplumuna kadar süregelen zaman zarfinda pek çok düşünür ve araştırmacı liderin izleyiciler, gruplar ve örgütün bütünü üzerindeki etkilerini araştırmıştır. Liderlik olgusunun tarihsel gelişimi incelendiğinde koşul, durum ve kültürel bağlamda farklı liderlik yaklaşımlarının ortaya çıktı̆̆ gözlemlenmiştir. Bunun sebebi, toplumların sürekli bir değişim ve gelişim içerisinde olmalarından kaynaklanmaktadır (Hodgetts, Luthans, 2003). Geçerli olan liderlik yaklaşımları da yaşanılan bu değişimler 1şı̆̆ında gelişerek yeni liderlik tarzlarının ortaya çıkmasını sağlamaktadır. 
1980'li yıllarda başlayan finansal ve siyasi serbestleşme süreci, 1990'l1 yıllara gelindiğinde bilgi ve teknoloji alanlarındaki gelişmeler ile birleşerek küreselleşme olgusunu ortaya çıkarmıştır. Bununla birlikte yaygınlaşan sermaye hareketleri, iletişim ve bilgi teknolojilerindeki gelişimlere bağlı olarak ulusal sermaye hareketlerinin hacmini arttırmış; dünyadaki tüm finansal aktörleri birbirlerine bağımlı hale getirmiştir. Sermaye hareketlerinin bütünleşmesi ile yönetsel kararlarda etik dışı sapmalar, etkileri küresel çapta hissedilen krizlere yol açmıştır. Yeni küresel düzende, işletmelerde verilen kararların sonuçları artık sadece hissedarları değil tüm paydaşları etkilemektedir (Turan, 2011). Bu bağlamda şirket yönetimi tüm paydaşlarına karşı şeffaf, hesap verilebilir, sorumlu ve adil olma zorunluluğu ile karşı karşıya kalmıştır. Yönetim ve sahipliğin birbirinden ayrılması; şirket hisselerinin yaygınlaşması ile birlikte pay sahiplerinin yönetim üzerindeki denetiminin zayıflaması yönetim ile pay sahipliği arasındaki ilişkiye yeni bir boyut kazandırmıştır (Menteş, 2008). Bu güncel gelişmeler ışığında modern liderlik yaklaşımlarının bakış açısı değişim göstermiştir.

Çokuluslu işletmelerin farklı kuşak ve kültürleri bir arada bulundurması ile bu farklılıkların yönetiminin ön plana çıkması; insanın işletmenin en önemli stratejik kaynağ 1 haline dönüşmesi, liderlik yaklaşımlarında evrensel ilke ve değerlerin merkezileşmesini zorunlu kılmaktadır. Bu noktada etik değerlerin diğer güncel liderlik yaklaşımlarında normatif yönü ile ele alınması; liderliğin önemli bir bileşeni olan etkileşimci özelliğinin göz ardı edilmesi etik liderliğin gelişimine zemin hazırlamıştır. Böylelikle etik lider "eylemlerinde ve kişilerarası ilişkilerinde normatif uygunluk dâhilinde yönetim sergileyen; izleyicilerle iki yönlü iletişimi pekiştirmeyi ve ahlaki düşünce yapısını teşvik eden bir liderlik yaklaşımı" şeklinde Brown, Trevino ve Harrison tarafindan literatüre kazandırılmıştır. Brown, Trevino ve Harrison'ın etik liderlik tanımında "liderin normatif uygunluk çerçevesinde davranışlar sergilemesi”, lider davranışının dürüstlük, güvenirlik, tarafsızlık, adalet gibi özellikleri vurgulayarak liderin güvenilir bir rol model olmasını ifade etmektedir. Tanımın diğer boyutu ise liderin izleyici davranışlarını etkilemesi üzerine temellendirilmiştir. Böylece etik lider sadece etik davranışlar sergilemekle kalmamakta; aynı zamanda iletişim araçları kullanarak bu davranışların izleyiciler tarafından benimsenmesini de sağlamaktadır. Pekiştirme veya güçlendirmeye dayanan bu davranış, etik standartlar çerçevesinde faaliyetlerini şekillendiren izleyicilerin ödüllendirilmesi ve uymayanların cezalandırması esasına dayanmaktadır (Brown, Trevino, Harrison, 2005).

\section{II. ÖRGÜTSEL VATANDAŞLIK DAVRANIŞI (ÖVD) VE ÖVD İLE ETIK LIDERLİK İLIŞKİSI}

Küreselleşen iş dünyasında işletmelerin sürdürülebilirliğinde birey çıkarları ile kurum çıkarlarının uyumlaştırılması önemli bir yere sahiptir. Örgütsel verimlilik, değişen çevresel koşullara uyum arayışında ve sürdürülebilir örgütsel başarının sağlanması üzerinde olumlu etkisi olan biçimsel rol ötesi davranışlar ön plana çıkmaktadır. Bu bağlamda biçimsel rol ötesi davranışlar olarak ifade edilen 
örgütsel vatandaşlık davranışı (ÖVD) Dennis W. Organ ve arkadaşları tarafından literatüre kazandırılmıştır (Organ, 1988). Çalışmada ÖVD, çalışanların gönüllülük esasına dayanan; biçimsel rol gereksinimlerinin ötesinde örgütsel fayda sağlayan davranışlar bütünü olarak ifade edilmiştir. ÖVD kapsamında ele alınan gönüllülük esası, çalışanların biçimsel rol tanımlarında ve sözleşmeleri kapsamında bulunmayan davranış kalıplarını içermektedir. İş görenlerin sergiledikleri ÖVD, örgütte sosyal yapıyı meydana getiren dayanışmacı-işbirlikçi davranışların oluşumunda ve karşıllklı ilişkilerin olumlu yönde harekete geçirilmesinde önem kazanmaktadır (Organ, 1988; D. Organ, 1990; Podsakoff, Ahaerne, MacKenzie, 1997).

Çalışmada ÖVD, Organ tarafından ele alınan 5 boyut kapsamında ele alınmıştır. İlk boyut olan özgecilik bireylerin diğer örgüt üyelerine karşıllk beklemeksizin yardım etmelerini ve örgüt içerisinde çatışmaların önlenmesine yönelik gönüllü davranışlarını içermektedir (Organ,1988). Özgecilik aynı zamanda bir çalışanın diğerlerine işle ilgili herhangi bir sorunla karşılaşıldığında gönüllü olarak gösterdiği yardım etme davranışı olarak ifade edilmektedir (Podsakoff, MacKenzie, 1997). İşe yeni giren bir çalışanın oryantasyonu, iş yükü ağır olan çalışma arkadaşına yardım etme ve iş ile ilgili bilgi paylaşımı özgecilik davranışına örnek teşkil etmektedir.

ÖVD'nin ikinci boyutu olan yüksek görev bilinci boyutu bireylerin örgütün kural ve prosedürleri çerçevesinde biçimsel rol gerekliliklerinin ötesine geçerek sergiledikleri davranışları içermektedir. Ayrıca, çalışma saatlerinin etkin ve verimli kullanımı ile zorlu şartlar altında görev gerekliliklerinin yerine getirilmesi bu boyuttaki davranışları kapsamaktadır. ÖVD'nin bir diğer boyutu olan centilmenlik/gönüllülük, çalışanların olumsuz davranışlardan kaçınarak, görev gerekliliklerinin zorlukları karşısında hoşgörü ile yaklaşım sergilemelerini ifade etmektedir. Örgütte çatışmalardan kaçınma davranışlarını temsil eden centilmenlik davranışı, çalışanların gönüllü olarak görevlerin getirdiği zorluklara karşı olumlu bir tavır sergilemesi olarak tanımlanmaktadır (Podsakoff v.d.,1990; Graham,1991; Podsakoff v.d.,2000).

Bireyin bütünsel olarak örgüte olan bağlılı̆̆ını ele alan örgüt gelişimine destek olma/ sivil erdem boyutu, çalışanların gönüllü olarak örgütsel konulara etkin katılımını, sorumluluk bilincini ve örgütsel konularda aktif bir rol üstlenmesi olarak değerlendirilmektedir. Örgüt gelişimin desteklenmesi adına bilgi paylaşımının sağlanması; örgüte ait bilgilerin saklanması gibi olumlu davranış kalıplarını içermektedir (Podsakoff v.d.,1990; Podsakoff v.d.,2000) Nezakete dayalı bilgilendirme boyutu ise sorunlar karşısında bireylerin olumlu tutumlarını ifade etmektedir. Bu boyut başkalarının hakları istismar edilmeden sorunların önlenmesi ve ortaya çıkabilecek sorunların tesirinin azaltılması yönünde sergilenen davranışlar bütünüdür (Organ, Podsakoff, MacKenzie,2006; Özkalp, 2003; İşbaş1,2000).

Araştırmacı tarafından yapılan litaratür taraması sonucunda Tablo 1'de etik liderlik ile ÖVD ilişkisini içeren çalışmalar özetlenmiştir. 
Tablo 1. Etik Liderlik ve Örgütsel Vatandaşlık Davranışı İlişkisi

\begin{tabular}{|c|c|c|}
\hline Yazar (lar) & Örneklem & Araştırma Sorunsalı ve Bulguları \\
\hline $\begin{array}{l}\text { Virgina } \\
\text { Humme, } \\
\text { Felice van } \\
\text { Laar }\end{array}$ & $\begin{array}{l}\text { Farklı sektörlerde çalışan } 159 \\
\text { işgören çalışma örneklemini } \\
\text { oluşturmaktadır. }\end{array}$ & $\begin{array}{l}\text { Çalışma etik lider tarzının iş görenlerin } \\
\text { ÖVD davranışı sergilemeleri üzerine } \\
\text { etkilerini ortaya koymaya yönelik } \\
\text { gerçekleştirilmiş olup önerilen } \\
\text { araçsallık ilişkisi çalışma sonuçları ile } \\
\text { desteklenmiştir. }\end{array}$ \\
\hline $\begin{array}{l}\text { Toor ve } \\
\text { Ofori, } 2009\end{array}$ & $\begin{array}{l}\text { Çalışma, } 62 \text { üst düzey yönetici ve } \\
\text { beraber çalıştıkları kıdemli } \\
\text { yöneticiler üzerinde } \\
\text { gerçekleştirilmiştir. }\end{array}$ & $\begin{array}{l}\text { Çalışmada, etik liderlik, dönüşümcü } \\
\text { liderlik, etkileşimci liderlik } \\
\text { yaklaşımları ile çalışan etkililiği ve } \\
\text { örgütsel vatandaşlık davranışı ilişkisi } \\
\text { ele alınmış olup söz konusu ilişkiler } \\
\text { çalışmanın verileri ile tespit edilmiş̧tir. }\end{array}$ \\
\hline $\begin{array}{l}\text { Mayer ve } \\
\text { Diğerleri, } \\
2009\end{array}$ & $\begin{array}{l}\text { Çalışma, } 160 \text { farklı örgütte } 195 \\
\text { farklı birim üzerinde } \\
\text { gerçekleştirilmiştir. Söz konusu } \\
\text { örgütler teknoloji, hizmet, üretim, } \\
\text { perakende ve sağlık kuruluşları } \\
\text { olarak ifade edilmiştir. }\end{array}$ & $\begin{array}{l}\text { Etik liderlik, örgütsel vatandaşlık } \\
\text { davranışı ve örgüt içerisinde } \\
\text { istenmeyen davranışlar arası ilişkinin } \\
\text { araştırılması çalışmanın ana } \\
\text { sorunsalıdır. Çalışma sonuçları } \\
\text { değişkenler arasında pozitif yönde ve } \\
\text { anlamlı ilişkiler ortaya koymuştur. }\end{array}$ \\
\hline $\begin{array}{l}\text { Piccolo et. } \\
\text { al.,2010 }\end{array}$ & $\begin{array}{l}\text { Çalışma, } 181 \text { çalışan üzerinde } \\
\text { gerçekleştirilmiştir. }\end{array}$ & $\begin{array}{l}\text { Çalışmada, etik liderlik, } \\
\text { gerçekleştirilen görevin önem derecesi, } \\
\text { görev özerkliği, çalışan performansı } \\
\text { gibi değerler arasındaki ilişki ortaya } \\
\text { koyulmuştur. Çalışma bulguları etik } \\
\text { liderliğin çalışanların örgütsel } \\
\text { vatandaşlık davranışı sergilemelerine } \\
\text { yol açtığını ispatlamıştır. }\end{array}$ \\
\hline $\begin{array}{l}\text { Kacmar, } \\
\text { Bachrach ve } \\
\text { Harris, } 2010\end{array}$ & $\begin{array}{l}\text { Çalışma tam zamanlı } 179 \text { ABD } \\
\text { hükümeti çalışanı üzerinde } \\
\text { gerçekleştirilmiştir. }\end{array}$ & $\begin{array}{l}\text { Çalışmada etik liderliğin birey odaklı } \\
\text { ve görev odaklı vatandaşlık } \\
\text { davranışının önemli belirleyicisi } \\
\text { olduğu, tespit edilmiştir. }\end{array}$ \\
\hline $\begin{array}{l}\text { Ruiz- } \\
\text { Palomino, } \\
\text { Ruiz-Amaya } \\
\text { ve } \\
\text { Knörr,2011 }\end{array}$ & $\begin{array}{l}\text { Çalışma } 525 \text { sigorta ve banka } \\
\text { çalışanı üzerinde } \\
\text { geçcekleştirilmiştir. }\end{array}$ & $\begin{array}{l}\text { Çalışmada etik liderlik ile örgütsel } \\
\text { vatandaşlık davranışı arasındaki ilişki } \\
\text { ortaya konularak; ilişkide iş tatmini ve } \\
\text { duygusal bağlılığın araçsallığı tespit } \\
\text { edilmiştir. }\end{array}$ \\
\hline $\begin{array}{l}\text { Philipp ve } \\
\text { Lopez, } 2013\end{array}$ & $\begin{array}{l}\text { Çalışma } 159 \text { çalışan üzerinde } \\
\text { gerçekleştirilmiştir. }\end{array}$ & $\begin{array}{l}\text { Çalışmada psikolojik sözleşmeler, etik } \\
\text { liderlik, örgütsel bağlılık ve örgütsel } \\
\text { vatandaşlık davranışı arasındaki ilişki } \\
\text { araştırılmış; çalışma sonuçları etik } \\
\text { liderliğin psikolojik sözleşme ve } \\
\text { örgütsel vatandaşlık davranışı } \\
\text { ilişkisininde araçsallığı ispatlamıştır. }\end{array}$ \\
\hline
\end{tabular}


Tablo 1'deki çalışmalardan ilki Hollanda'da farklı sektörlerde görev alan 159 çalışan üzerinde gerçekleştirilmiştir. Bu çalışmanın temel amacı etik lider tarzının bireylerin ÖVD sergilemeleri üzerindeki etkisinin saptanmasıdır. Çalışma bulguları liderin etik ve adaletli davranışı, rol gerekliliklerinin yerine getirilmesi ile güç paylaşımı boyutları ile sivil erdem, nezakete dayalı bilgilendirme ile özgecilik üzerinde güçlü etkisini ortaya koymaktadır. (Humme, van Laar, 2008)

Toor ve Ofori ise (2009) yılındaki çalışmada etik lider, çalışan etkililiği ve örgütsel vatandaşlık arasında anlamlı ve pozitif yönde bir ilişki ispatlanmıştır. Singapur'da 62 üst düzey yönetici ve bu yöneticilerin beraber çalıştıkları kıdemli yöneticiler üzerinde yapılan bu çalışmada, etik liderlik, pozitif örgüt iklimi ve çalışanların örgütsel vatandaşlık davranışı sergilemeleri arasında pozitif yönlü ilişki tespit edilmiştir. Mayer ve diğerlerinin (2009) çalışmasında, etik liderlik üst düzey yöneticiden bölüm yöneticilerine doğru akış gösteren bir model olarak ifade edilmektedir. Çalışmada, etik liderliğin örgütsel vatandaşlık davranışı üzerine etkisi araştırılmıştır. Araştırma sonuçları etik liderliğin çalışanların örgütsel vatandaşlık davranışı sergilemelerine yol açtığı; olumsuz ve istenmeyen davranışlardan ise kaçınmalarını sağladığını ortaya koymaktadır. Piccolo ve diğerlerinin (2010) 181 çalışan üzerinde gerçekleştirdikleri çalışmada etik liderliğin, ÖVD üzerine etkisi incelenmiştir. Turizm, sağlı, emlak, eğitim, perakende ve finans sektörleri gibi çeşitli sektörlerde gerçekleştirilen çalışmada etik lider davranışlarının ÖVD üzerine etkisi tespit edilmiştir. Çalışmada etik lider davranışlarının ÖVD'nin bir belirleyicisi/öncülü olduğu ifade edilmiştir. Kacmar, Bachrach ve Harris'in (2010) yapmış olduğu çalışmada ise etik liderlik ve örgütsel vatandaşlık davranışı arasında istatiksel olarak anlamlı ve pozitif yönde bir ilişki ispatlanmıştır. Çalışmada, etik liderliğin çalışanların örgütsel vatandaşlık sergilemeleri üzerinde kuvvetli bir etkiye sahip olduğu belirtilerek, etik liderlik ÖVD’nin belirleyicisi olarak değerlendirilmiştir. Çalışma, Sosyal Mübadele Teorisi kapsamında ele alınarak; çalışanların etik lidere karşı olan yükümlülüklerini, örgütsel vatandaşlık davranışı sergileyerek yerine getirdikleri sonucuna varılmıştır. Böylelikle çalışmada etik liderin varlığının çalışanların yoğun bir şekilde örgütsel vatandaşlık davranışı sergilemelerine yol açan belirleyici olduğu belirtilmektedir.

Ruiz- Palomino, Ruiz-Amaya ve Knörr'ün (2011) İspanya'da bankacılık ve sigorta sektörlerinde 525 çalışan üzerinde etik liderlik, iş tatmini, duygusal bağlılık ve örgütsel vatandaşlık davranışı ilişkisini incelemiştir. Çalışmada kavramlar arasında istatiksel olarak pozitif yönde, anlamlı ilişkiler tespit edilmiştir. Araştırma bulguları etik liderliğin çalışanların örgütsel vatandaşlık sergilemeleri üzerindeki etkisinde iş tatmini ve duygusal bağlılığın araçsallığını ispatlamıştır. Philipp ve Lopez'in (2013) etik liderlik ve örgütsel vatandaşlık davranışları arasındaki ilişkiyi inceledikleri çalışmada benzer şekilde etik liderliğin çalışanların örgütsel vatandaşlık davranışı sergilemeleri üzerindeki olumlu yönde etkisi tespit edilmiştir. Çalışma 5 haftalık araştırma süreci çerçevesinde farklı endüstrilerde çalışan 159 kişi üzerinde gerçekleştirilmiş olup; 
araştırma kapsamındaki sektörler eğitim, askeri ve sağlık sektörü olarak belirtilmiştir.

\section{ETIKK LIDERLIĞİN ÖRGÜTSEL VATANDAŞLIK DAVRANIŞI ÜZERINE ETKISINNDE ÖRGÜTSEL ÖZDEŞLEŞMENIN ARACILIK ROLÜ}

İşletmeler doğası itibari ile bireylerin sürekli bir biçimde etkileşimde bulundukları, ortak hedefe ulaşma yolunda gönüllü olarak katkı sağladıkları bir sosyal sistemdir. Bireylerin sergiledikleri ve rol tanımlarında yer alan davranış kalıpları örgütün etkinliği ve verimliliği noktasında önem taşımaktadır ancak tek başına yeterli değildir. Bu çerçevede işletmelerin etkin ve verimli bir biçimde işleyişi adına bireylerin dayanışma içerisinde sergiledikleri gönüllü davranışlar ön plana çıkmaktadır. Bir önceki başlıkta ÖVD sergileyen bireylerin gönüllü olarak örgütsel gelişim ile ilgili konularda aktif katılım sağladıkları ve bu doğrultuda davranış ve tutumlar sergiledikleri ifade edilmiştir. (Podsakoff, MacKenzie, 1997; Organ, Podsakoff, MacKenzie, 2006).

Literatürde çeşitli çalışmalar örgütsel vatandaşlık davranışı ve etik liderlik ilişkisi ile birlikte, örgütsel özdeşleşme ile örgütsel vatandaşlık davranışı arasında pozitif yönde bir ilişkinin varlığını ortaya koymaktadır. Bu çalışmalardan ilki Mael ve Ashforth (1992) tarafından gerçekleştirilmiştir. Yazarlar örgütleri ile özdeşleşen bireylerin daha yoğun özgecilik davranışı sergilediklerini tespit etmiştir. 297 üniversite mezunu üzerinde yapılan bu çalışmada, bireylerin örgüt ile özdeşleşmelerinde belirleyici faktörler; duygusal bağ ve tatmin derecesi şeklinde ifade edilirken, örgütsel özdeşleşme, özgecilik davranışını oluşturan önemli bir etken olduğu belirtilmiştir. Bergami ve Bagozzi (2002) Kore ve İtalya'da gerçekleştirilen çalışma ise yüksek derecede özdeşleşen çalışanların daha yoğun örgütsel vatandaşlık davranışı sergilediklerini ortaya koymaktadır. Dukerich ve diğerlerinin (2002) 1504 doktor üzerinde gerçekleştirdikleri çalışmada, örgütsel özdeşleşme ile örgütsel vatandaşlık davranışı arasındaki ilişki araştırılmıştır. Çalışma sonuçları örgütsel özdeşleşmenin, örgütsel vatandaşlık davranış1 üzerinde olumlu yönde ve anlamlı bir etkisini ispatlamıştır. Bell ve Mengüç'ün (2002) 228 sigorta satış elemanı üzerinde yaptıkları çalışmada örgütsel özdeşleşmenin, örgütsel vatandaşlık davranışının tüm boyutları üzerinde istatiksel olarak anlamlı bir etkisi görülmüştür. Christ ve diğerlerinin (2003) Almanya'da, 447 öğretmen üzerinde gerçekleştirdikleri araştırma ise bireylerin örgütsel özdeşleşme düzeyleri ile örgütsel vatandaşlık davranışı arasındaki ilişki ele alınmıştır. Araştırma bulguları bireylerin örgütleri ile özdeşleşmelerinin hem örgüte yönelik hem de gruba yönelik örgütsel vatandaşlık sergilemeleri üzerindeki güçlü etkisini ortaya koymaktadır.

Feather ve Rauter (2004) Avustralya'da, 101 tam zamanlı ve 53 sözleşmeli öğretmen üzerinde gerçekleştirdikleri çalışmada, çalışanların kadrolu/sözleşmeli olma durumlarının örgütsel özdeşleşme ve örgütsel vatandaşlık davranış1 üzerindeki etkisi araştırılmıştır. Araştırma sonucunda kadrolu/tam zamanlı çalışan öğretmenlerin, çalıştıkları örgüt ile özdeşleşme düzeyleri ve örgütsel vatandaşlık sergilemeleri arasında anlamlı pozitif bir ilişki ortaya konmuştur. Diğer bir ifade 
ile araştırma sonuçları bireylerin özdeşleşme düzeyleri yükseldiğinde, ÖVD sergileme düzeylerinin de arttığına işaret etmektedir. Van Dick ve diğerleri (2004) yılında Almanya'da gerçekleştirilen bir başka çalışma ise birleşme koşulları çerçevesinde ele alınmıştır. Şirket birleşmesi sonrası 459 çalışan üzerinde yapılan çalışmada, örgütsel özdeşleşme düzeyi yüksek olan bireylerin daha fazla örgütsel vatandaşlık davranışı sergilediklerini tespit etmektedir. Karabey ve İşcan'ın (2007) Erzurum'da iki farklı işletmede 83 çalışan üzerinde gerçekleştirdikleri çalışmada ise, bireylerin örgütsel özdeşleşme düzeyleri ile örgütsel vatandaşl1k sergilemeleri arasında pozitif ve istatistiksel zeminde anlamlı bir ilişki olduğu gözlemlenmiştir. Söz konusu olumlu ilişkinin ÖVD'nin tüm boyutlarını da kapsadığ çalışmada ifade edilmektedir. Konu üzerine Vondey (2010) tarafindan ortaya konulan bir başka çalışma ABD'de farklı sektörlerde çalışan 130 kişi üzerinde gerçekleştirilmiştir ve örgütsel özdeşleşmenin ÖVD üzerinde pozitif ve istatistiksel olarak anlamlı bir etkisi olduğu tespit edilmiştir. Böylelikle literatürde yapılan ampirik çalışmalar örgütsel özdeşleşme ile ÖVD arasında anlamlı bir ilişkiyi ortaya koymaktadır.

Çalışma kapsamında ilgili literatür analizi sonuçları etik liderlik ile örgütsel vatandaşlık davranışı arasında ve etik liderlik ile örgütsel özdeşleşme arasında bir ilişkiyi ortaya koymaktadır. Ancak, etik liderlik ile örgütsel vatandaşlık davranış1 ilişkisinde, örgütsel özdeşleşmenin aracılık etkisini içeren çalışma bulunmamaktadır. $\mathrm{Bu}$ nedenle çalışmada etik liderlik ile örgütsel vatandaşlık davranışı ilişkisinde, iş tatmini ve duygusal bağl1lık gibi farklı faktörlerin yer alması sebebi ile örgütsel özdeşleşmenin kısmi aracılık etkisi araştırılacaktır.

\section{ARAŞTIRMANIN BULGULARI VE DEĞERLENDİRILMESI}

\section{A. Araştırmanın Konusu}

Çalışmanın amacı, etik liderlik ile örgütsel vatandaşlık davranışı ilişkisinde örgütsel özdeşleşmenin aracılık etkisinin değerlendirilmesidir. Çalışmadaki temel varsayım, lider davranışlarının izleyicilerin örgütlerine yönelik tutumlarını etkilediğidir. $\mathrm{Bu}$ doğrultuda etik lider davranışlarının, bireylerin örgütleri ile özdeşleşmelerini sağlayarak, örgütsel vatandaşlık davranışı sergilemeleri üzerinde olumlu yönde etkisi olduğu düşünülmektedir. Araştırmanın ana kütlesi Türkiye Bankalar Birliği (TBB)'ne üye mevduat banka çalışanlarıdır. Araştırma süreci tarihi itibarı ile TBB'ye bağlı toplam 47 adet mevduat bankası bulunmaktadır (Türkiye Bankalar Birliği (TBB) Banka ve Sektör Bilgileri, 2015). Araştırma sürecinde İstanbul'daki kamu sermayeli, özel ve yabancı sermayeli ticari bankalara 700 adet anket dağıtılmıştır. Çalışmanın sonucunda 424 adet kullanılabilir ankete ulaşılmıştır. Geri dönüş oranı \% 60,5'tir. Eylül 2014 tarihi itibari ile İstanbul'da mevduat bankalarında çalışan sayıs1 195,363 kişi olarak tespit edilmiştir (Türkiye Bankalar Birliği (TBB) Personel ve Şube Sayıları, 2015) Araştırmanın anketini dolduracak birey sayısı örnekleme formülü kullanılarak \%5 hata payı ile en az 384 kişi olarak hesaplanmıştır (Orhunbilge, 1997).

\section{B. Araştırmanın Önemi ve Yöntemi}

Etik lider, adil bir ödül sistemi, ortak normlar ve değerler oluşturma gibi davranışları ile çalışanlar üzerinde olumlu bir etkiye sahiptir. Bu noktada 
bireylerin örgütlerine yönelik olumlu tutum sergilemeleri, liderin etik davranışlarının birer sonuçları olarak değerlendirilmektedir. Literatürde ampirik ve teorik çalışmalarla kanıtlanmış etkileri ile etik liderlik, aynı zamanda gelişmekte olan bir çalışma alanıdır. Bu sebeple etik liderin, izleyicilerin örgütlerine yönelik tutumları üzerinde etkilerinin ortaya çıkarılması önem taşımaktadır. Çalışmadaki temel varsayım, lider davranışlarının izleyicilerin örgütlerine yönelik tutumlarını etkilediğidir. $\mathrm{Bu}$ doğrultuda etik lider davranışlarının, bireylerin örgütleri ile özdeşleşmelerini sağlayarak, örgütsel vatandaşlık davranışı sergilemeleri üzerinde olumlu yönde etkisi olduğu düşünülmektedir.

Çalışmanın temel amacı, mevduat bankalarında, etik lider davranışlarının örgütsel özdeşleme ve ÖVD'nin gerçekleşmesinde ne derece belirleyici ve katkı sağlayıcı olduğunun araştırılmasıdır. Bununla birlikte, literatürde etik lider davranış boyutlarının örgütsel özdeşleşme üzerinde ve ÖVD boyutları üzerinde etkilerinin araştırıldığı çalışmaya rastlanılmaması ve literatürde bu alanda bir eksikliğin tespit edilmesidir.

Çalışmanın önceki bölümlerinde incelenen kavramsal çerçeve ile desteklenen araştırma modeli geliştilirilmiş olup; modelin analizine yönelik hipotezler geliştirilmiştir. Araştırmada ele alınan her bir değişken ilgili ölçekler ile değerlendirilerek, değişkenler faktör analizi sonrasında ortaya çıkacak boyutları ile ele alınacaktır.

Model ile ilgili belirtilen hipotezler aşağıdaki gibidir;

H1: Etik liderliğin ÖVD üzerinde etkisi vardır.

H2: Etik liderliğin örgütsel özdeşleşme üzerinde etkisi vardır.

H3: Örgütsel özdeşleşmenin ÖVD üzerinde etkisi vardır.

H4: Etik liderliğin ÖVD üzerindeki etkisinde örgütsel özdeşleşmenin kısmi aracılık etkisi vardır.

Araştırmanın ana kütlesi TBB'ye üye mevduat banka çalışanlarıdır. Araştırma 15 Aralık 2014 ile 15 Mart 2015 tarihleri arasında tamamlanmıştır. Bu araştırmada amaç olgular arasındaki neden ve sonuç ilişkilerini ortaya çıkarılması ve mevcut durumun tespit edilmesidir. Bu yönü ile çalışma açıklayıcı nitelikte bir araştırma şeklinde tanımlanabilmektedir. Çalışma kapsamında özellikle mevduat bankalarının seçilmesinin öncelikli sebebi Türkiye Bankalar Birliği’ne (TBB) bağlı 47 adet bankanın büyük çoğunluğunu mevduat bankalarının oluşturmasıdır (\%72). Mevduat bankaları 11,182 şube ile Türkiye genelinde faaliyet göstermektedir. Kalkınma ve yatırım bankaları sermaye yapılarının farklılığ nedeni ile çalışma kapsamına dâhil edilmemiştir.

Araştırmada veri toplama yöntemi anket uygulamasıdır. Çalışmanın anket formu dört bölümden oluşmaktadır. Anket formunun ilk bölümünde, araştırmaya katılan çalışanların demografik özelliklerinin belirlenmesine yönelik soruları kapsamaktadır. Anket formunun ikinci bölümünde çalışanların birim yöneticilerine ilişkin algılarını ölçme amaçlı De Hoogh ve Den Hartog tarafından geliştirilen 5'li Likert tipi ölçeği kapsamında 17 sorudan oluşan Brislin ve diğerleri tarafından önerilen yöntem çerçevesinde Türkçe'ye çevirisi yapılan 
(Palalar Alkan, 2015) Etik Liderlik Ölçeği kullanılmıştır. De Hoogh ve Den Hartog tarafından geliştirilen çok boyutlu ölçek, etik lider davranışlarını farklı boyutları ile ele alması ve bu davranışların örgütsel sonuçlarını değerlendirmesi ile etik liderliğe çok boyutlu bir yaklaşım kazandırmaktadır. Anket formunun üçüncü bölümü banka çalışanlarının bankaları ile özdeşleşme düzeylerini belirlemeye yöneliktir. $\mathrm{Bu}$ noktada çalışanların kurumları ile özdeşleşme düzeylerini belirleme amacı ile Mael ve Ashforth (1992) tarafindan geliştirilen Türkçeye uyarlaması Tak ve Aydemir (2004) tarafından yapılan 6 maddeli örgütsel özdeşleşme ölçeği kullanılmıştır. Anket formunun son bölümünde ise bireylerin örgütsel vatandaşlık davranışlarını ölçme amacıyla Podsakoff ve Mackenzie (1998) tarafından Organ'ın (1988) örgütsel vatandaşlık davranışın beş boyutuna dayalı olarak hazırladıkları ve daha sonra Podsakoff, MacKenzie, Moorman ve Fetter (1990) ve Moorman (1991) tarafindan geliştirilen; Aksoy (2012) tarafindan Türkçeye uyarlanan 20 soruluk "Örgütsel Vatandaşlık Davranışı Ölçeği” kullanılmıştır.

Çalışmada elde edilen veriler SPSS (Statistical Package for Social Sciences) for Windows 21.0 programı kullanılarak analiz edilmiştir. Araştırmanın bağımlı ve bağımsız değişkenleri arasındaki ilişki Pearson korelasyon, etki ise hiyerarşik regresyon analizi ile test edilmiş olup ve istatistiksel anlamlılık düzeyi 0.05 olarak belirlenmiştir.

\section{Araştırmanın Bulguları ve Değerlendirmesi}

Anketi cevaplayan örneklemdeki 424 banka çalışanının sosyo-demografik özelliklerine göre dağılımı ele alınmıştır. Katılımcıların \%45,8'i erkek, \%54,2'si kadın çalışanlardan oluşmaktadır. Ayrıca ankete katılanların büyük çoğunluğunun üniversite mezunu olduğu anlaşılmaktadır (\% 65,1). Çalışmaya katılanların yaş aralığının geniş olmasından dolayı çalışan yaşları dört yaş grubunda toplanmıştır, ancak katılımcıların neredeyse yarısının $(\% 47,9)$ 26-33 yaş arasında olduğu görülmektedir. $\mathrm{Bu}$ veriler ışığında, araştırma örnekleminin büyük çoğunluğunun 26-33 yaş aras1, yükseköğrenim görmüş çalışanlardan oluştuğu söylenebilir. Araştırma örneklemi banka çalışanları pozisyonları müdür yardımcısı, uzman, uzman yardımcısı, şef ve memur olarak sınıflandırılmıştır. Çalışmaya katılanların büyük çoğunluğunu memur $(\% 32,3)$ ve şef $(\% 21,9)$ pozisyonunda görev alanlar oluşmaktadır. Anketi cevaplayan banka çalışanlarının pozisyon kıdemi aralığı geniş olduğundan söz konusu süreler beş grupta toplanmıştır. Katılımcıların yarısına yakın bir çoğunluğunun kıdem yılının 1-3 yıl arasında olduğu anlaşılmaktadır $(\% 38,4)$. Katılımcıların örgüt kıdemi değişkenine göre sınıflandırılmasında benzer şekilde neredeyse yarısının 1-3 yıl arasında bir örgüt k1demine sahip olduğu gözlemlenmiştir $(\% 35,6)$. 
Tablo 2 Araştırmaya Katılan Çalışanların Demografik Özellikleri

\begin{tabular}{|c|c|c|c|c|c|}
\hline & Frekans(n) & $\begin{array}{l}\text { Yüzde } \\
(\%)\end{array}$ & & Frekans(n) & $\begin{array}{l}\text { Yüzde } \\
(\%)\end{array}$ \\
\hline \multicolumn{3}{|l|}{ Cinsiyet } & \multicolumn{3}{|l|}{ Pozisyon } \\
\hline Erkek & 194 & 45,8 & Memur & 137 & 32,3 \\
\hline Kadın & 230 & 54,2 & Uzman Yrd. & 37 & 8,7 \\
\hline \multicolumn{3}{|c|}{ Medeni Durum } & Uzman & 111 & 26,2 \\
\hline Evli & 240 & 56,6 & Şef & 93 & 21,9 \\
\hline Bekar & 184 & 43,4 & Müdür Yrd. & 46 & 10,8 \\
\hline \multicolumn{3}{|c|}{ Eğitim Durumu } & \multicolumn{3}{|c|}{ Pozisyon Kıdemi } \\
\hline Önlisans & 55 & 13,0 & 1 Y1ldan Az & 85 & 20,0 \\
\hline Üniversite & 276 & 65,1 & 1-3 Y1l & 163 & 38,4 \\
\hline Y.Lisans & 93 & 21,9 & $3-5$ Yil & 84 & 19,8 \\
\hline \multicolumn{3}{|l|}{ Yaş Grubu } & 5-8 Yil & 57 & 13,4 \\
\hline $18-25$ & 69 & 16,3 & 8 Y1l Ve üzeri & 35 & 8,3 \\
\hline $26-33$ & 203 & 47,9 & \multicolumn{3}{|l|}{ Örgüt Kıdemi } \\
\hline $34-41$ & 111 & 26,2 & 1 Yildan Az & 88 & 20,8 \\
\hline $42-49$ & 41 & 9,7 & 1-3 Yil & 151 & 35,6 \\
\hline \multicolumn{3}{|l|}{ Pozisyon } & 3-5 Yil & 61 & 14,4 \\
\hline Memur & 137 & 32,3 & 5-8 Yil & 29 & 6,8 \\
\hline Uzman Yrd & 37 & 8,7 & 8 Yil Ve üzeri & 95 & 22,4 \\
\hline
\end{tabular}

Etik liderlik, örgütsel özdeşleşme ve örgütsel vatandaşlık davranışının ölçümlenmesinde kullanılan ölçeklerin yapı geçerliğini ortaya koymak amacı ile bir dizi temel bileșen ve faktör analizi yapılmıştır. Araştırma kapsamında kullanılan tüm ölçeklerin yap1 geçerliliğinin sağlanması adına keşfedici faktör analizi uygulanmış ve birbirinden bağımsız alt boyutlar üretebilmek amacı ile verimax (orthogonal faktör rotasyonu) yöntemi kullanılmıştır. Etik liderlik ölçeği on yedi maddeden oluşmaktadır. Faktör analizinde güç paylaşımı alt boyutuna ait 3. ve 5. sorular görevlerin/ rollerin açıklığa kavuşturulması boyutuna çok yakın değerlerle yüklendiğinden maddeler ölçek dışı bırakılmıştır. Etik Liderlik ölçeğindeki 15 maddenin güvenirliğini hesaplamak için iç tutarlılık katsayısı olan "Cronbach Alpha" hesaplanmıştır. Ölçeğin genel güvenirliğinin yüksek düzeyde olduğu görülmektedir (alpha $>0,80)$. Ölçeğin yapı geçerliliğini ortaya koymak için açıklayıcı(açımlayıcı) faktör analizi yöntemi uygulanmış; yapılan Barlett testi sonucu $(\mathrm{p}=0.000<0.05)$ faktör analizine alınan değişkenler arasında ilişki tespit edilmiştir. Yapılan KMO test sonucunda $(\mathrm{KMO}=0.803>0,60)$ örnek büyüklügünün faktör analizi uygulanması için yeterli olduğu tespit edilmiştir. Faktör analizi uygulamasında varimax yöntemi seçilerek faktörler arasındaki ilişki yapısının aynı kalması sağlanmıştır. Faktör analizi sonucunda değişkenler, toplam açıklanan varyansı \%62.327 olan 3 faktör altında toplanmıştır. Etik liderlik ölçeğinin geçerliliği tespit edildikten sonra alt boyutların (faktörlerin) güvenirliğini ölçmek için Cronbach Alpha değerleri ölçülmüştür. Ölçekteki faktörlerin puanları hesaplanırken faktördeki maddelerin değerleri toplandıktan sonra madde sayısına bölünerek (aritmetik ortalama) faktör puanları elde 
D. Palalar Alkan \& F. Ş. Arıkboğa / Etik Liderlik ve Örgütsel Vatandaşlık Davranışı İlişskisinde Örgütsel Özdeşleşmenin Aracllik Etkisi ve Bir Uygulama edilmiştir. On beş madde kullanılarak yapılan etik liderlik ölçeğinin üç faktörlü bir yapı göstermesi öngörülmüştür. Bu beklentiyi sınamak amacı ile temel bileşen analizi yapılarak bileşen sayısı üçe zorlanmıştır. Analiz sonuçları maddelerin yüksek katsayılarla üç bileşen altında toplanabileceğini göstermiştir.

Tablo 3 Etik Liderlik Ölçeği ve Alt Boyutlarının Güvenilirlik Sonuçları

\begin{tabular}{|l|c|}
\hline \multicolumn{1}{|c|}{ Etik liderlik Alt Boyutları } & Güvenirlik \\
\hline Etik Ve Adalet & 0,818 \\
\hline Görevlerin/rollerin Açıklığa Kavuşturulması & 0,904 \\
\hline Güç Paylaşımı & 0,713 \\
\hline Etik Liderlik Ölçeği & $\mathbf{0 . 8 8 4}$ \\
\hline \multicolumn{2}{|c|}{ KMO $=0.835>0,60$; Barlett Küresellik Test sonucu: $\mathrm{p}=0.000<0.05$} \\
\hline
\end{tabular}

Etik liderlik ölçeğinin güvenirliği hesaplandıktan sonra araştırmanın aracı değişkeni olan Örgütsel Özdeşleşme Ölçeği'ndeki 6 maddenin güvenirliğini ölçmek için alpha katsayısı hesaplanmış $(0,60<$ alpha $<0,80)$ ve ölçeğin güvenilir olduğu tespit edilmiştir. Ölçeğin yapı geçerliliğini ortaya koymak için yapılan açıklayıcı(açımlayıcı) faktör analiz sonucunda, toplam açıklanan varyansı $\% 47.649$ olan tek faktörlü yapı desteklenmiştir.

Tablo 4 Örgütsel Özdeşleşme Ölçeği Faktör Yapısı

\begin{tabular}{|c|c|}
\hline Madde & Faktör 1 \\
\hline ö̈1 & 0,618 \\
\hline ö̈2 & 0,645 \\
\hline öö3 & 0,788 \\
\hline ö̈4 & 0,730 \\
\hline ö̈5 & 0,571 \\
\hline ö̈6 & 0,762 \\
\hline
\end{tabular}

$\mathrm{KMO}=0.763 / 0,60$; Barlett Küresellik Test sonucu: 0,000<0,001

Son olarak araştırma kapsamında Örgütsel Vatandaşlık Davranışı Ölçeği'ndeki 20 maddenin güvenirliğini hesaplamak için iç tutarlılık katsayısı hesaplanmış; güvenirliği çok yüksek bulunmuştur (alpha>0,80) (Kalaycı v.d., 2008). Tablo 22 'den görüldüğü üzere örnek büyüklügünün faktör analizi uygulanması için yeterli olduğu anlaşılmış; değişkenler toplam açıklanan varyans $1 \% 64.304$ olan 5 faktör altında toplanmıştır.

Tablo 5 Örgütsel Vatandaşlık Davranışı Ölçeği Faktör Analizi Sonuçları

\begin{tabular}{|l|c|c|}
\hline \multicolumn{1}{|c|}{ Faktörler } & Özdeğer (Eigenvalue) & Açıllanan Varyans \\
\hline Özgecilik & 1.436 & 11,693 \\
\hline Nezakete Dayalı Bilgilendirme & 6.523 & 15,591 \\
\hline Centilmenlik/gönüllülük & 2.181 & 13,568 \\
\hline İleri Görev Bilinci & 1.143 & 10,769 \\
\hline $\begin{array}{l}\text { Sivil Erdem/örgüt Gelişimine } \\
\text { Destek Olma }\end{array}$ & 1.578 & 12,683 \\
\hline
\end{tabular}

$\mathrm{KMO}=0.835>0,60$; Barlett Küresellik Test sonucu: $\mathrm{p}=0.000<0.05$ 
Çalışma kapsamında ele alınan değişkenler arası ilişkinin yönünü ve değerini belirlemede korelasyon analizinden yararlanılmıştır. Bu çalışmada değişkenler arası ilişkisinin belirlenmesinde uygulamada sıklıkla kullanılan Pearson korelasyon analizi kullanılmıştır.

Tablo 6 Pearson Korelasyon Katsayısı Yorumu

\begin{tabular}{|c|c|}
\hline $\mathbf{r}$ & İLişKí \\
\hline $0,00-0,25$ & Çok zayıf \\
\hline $0,26-0,49$ & Zayıf \\
\hline $0,50-0,69$ & Orta \\
\hline $0,70-0,89$ & Yüksek \\
\hline $0,90-1,00$ & Çok yüksek \\
\hline
\end{tabular}

Tablo 6'da iki değişken arasında Pearson korelasyon katsayısının yorumu belirtilmiştir (Kalaycı v.d., 2008:116). Pearson korelasyon katsayısı iki değişken arasındaki doğrusal ilişkinin derecesinin belirlenmesinde kullanılan analiz tekniğidir. Bu çerçevede söz konusu değerler -1 ile +1 arsında değişmektedir. $\mathrm{Bu}$ katsayının pozitif değer alması değişkenler arası ilişkinin doğru orantılı; negatif değerler alması ise negatif yönlü ilişkisinin olduğunu ortaya koymaktadır. Pearson katsayısı 1'e yaklaştıkça ilişkinin kuvveti artarken; 0 'a yaklaştıkça söz konusu ilişki azalmaktadır.

Korelasyon analizi sonuçları etik liderlik ile ÖVD arasında pozitif yönlü, anlamlı ve kuvvetli $(0,709)$ bir ilişki ortaya koymaktadır. Analizde etik liderlik boyutlarının örgütsel vatandaşlık boyutlarına etkileri ayrı ayrı dikkate alınmıştır. Analiz sonuçlarına göre etik liderlik ve boyutlarının hem ÖVD hem de ÖVD'nin tüm boyutları ile pozitif yönde ve anlamlı bir ilişki bulunmaktadır. Etik ve adalet boyutu nezakete dayalı bilgilendirme ve sivil erdem boyutlarıyla orta $(0,504 ; 0,533)$ centilmenlik/gönüllülük ve özgecilik boyutu ile zayıf $(0,371 ; 0,285)$ yüksek görev bilinci ile çok zayıf $(0,089)$ ilişkiye sahiptir. Görevlerin/rollerin açıklığa kavuşturulması boyutu ile sivil erdem ve özgecilik boyutlarıyla orta $(0,563 ; 0,527)$ nezakete dayalı bilgilendirme, centilmenlik/gönüllülük ve yüksek görev bilinci boyutlarıyla zayıf $(0,465 ; 0,440 ; 0,267)$ ilişkiye sahip olduğu görülmektedir. Güç paylaşımı ise sivil erdem boyutu ile orta $(0,552)$, nezakete dayalı bilgilendirme, centilmenlik/gönüllülük, özgecilik ve yüksek görev bilinci boyutlarıyla zayıf $(0,494 ; 0,387 ; 0,390 ; 0,99)$ ilişkiye sahiptir.

Tablo 7 Etik Lider Davranışları ile Çalışanın ÖVD Arasındaki İlişki

\begin{tabular}{|l|l|l|l|l|l|l|l|}
\hline & & $\begin{array}{l}\text { Özgecili } \\
\mathbf{k}\end{array}$ & Nezaket & Centilmenlik/ & $\begin{array}{l}\text { İleri } \\
\text { Görev } \\
\text { Bilinci }\end{array}$ & $\begin{array}{l}\text { Sivil } \\
\text { Erdem }\end{array}$ & ÖVD \\
\hline \multirow{2}{*}{ Etik Ve Adalet } & $\mathrm{r}$ & $0,285^{* *}$ & $0,504^{* *}$ & $0,371^{* *}$ & 0,089 & $0,533^{* *}$ & $0,522^{* *}$ \\
\cline { 2 - 7 } & $\mathrm{p}$ & 0,000 & 0,000 & 0,000 & 0,067 & 0,000 & 0,000 \\
\hline $\begin{array}{l}\text { Görevlerin } \\
\begin{array}{l}\text { Açılığa } \\
\text { Kavuşturulması }\end{array}\end{array}$ & $\mathrm{r}$ & $0,527^{* *}$ & $0,465^{* *}$ & $0,440^{* *}$ & $0,267^{* *}$ & $0,563^{* *}$ & $0,636^{* *}$ \\
\cline { 2 - 8 } & $\mathrm{p}$ & 0,000 & 0,000 & 0,000 & 0,000 & 0,000 & 0,000 \\
\hline
\end{tabular}


D. Palalar Alkan \& F. Ş. Arıkboğa /Etik Liderlik ve Örgütsel Vatandaşlık Davranışı İlişsisinde Örgütsel Özdeşleşmenin Aracılık Etkisi ve Bir Uygulama

\begin{tabular}{|l|c|l|l|l|l|l|l|}
\hline \multirow{2}{*}{ Güç Paylaşımı } & $\mathrm{r}$ & $0,390^{* *}$ & $0,494^{* *}$ & $0,387^{* *}$ & $0,099^{*}$ & $0,552^{* *}$ & $0,559^{* *}$ \\
\cline { 2 - 8 } Etik Liderlik & $\mathrm{p}$ & 0,000 & 0,000 & 0,000 & 0,041 & 0,000 & 0,000 \\
\hline & $\mathrm{r}$ & $0,494^{* *}$ & $0,604^{* *}$ & $0,496^{* *}$ & $0,192^{* *}$ & $0,680^{* *}$ & $0,709^{* *}$ \\
\cline { 2 - 7 } & $\mathrm{p}$ & 0,000 & 0,000 & 0,000 & 0,041 & 0,000 & 0,000 \\
\hline
\end{tabular}

Tablo 8'de bağımsız değişken etik liderlik ile aracı değişken örgütsel özdeşleşme ilişkisinin test edildiği Pearson Korelasyon analizinin sonuçlarını göstermektedir. Yapılan analizde etik liderliğin tüm boyutlarının örgütsel özdeşleşme üzerinde etkisi ayrı ayrı incelenmiştir.

Tablo 8 Etik Liderlik Davranışları ile Çalışanın Örgütsel Özdeşleşmesi Arasındaki İlişki

\begin{tabular}{|l|c|c|c|c|c|}
\hline & & $\begin{array}{c}\text { Etik Ve } \\
\text { Adalet }\end{array}$ & $\begin{array}{c}\text { Görevlerin/rollerin Açıklığa } \\
\text { Kavuşturulması }\end{array}$ & $\begin{array}{c}\text { Güç } \\
\text { Paylaşımı }\end{array}$ & $\begin{array}{c}\text { Etik } \\
\text { Liderlik }\end{array}$ \\
\hline $\begin{array}{l}\text { Örgütsel } \\
\text { Özdeşleşme } \\
\text { Ölçeği }\end{array}$ & $\mathrm{r}$ & $0,682^{* *}$ & $0,570^{* *}$ & $0,651^{* *}$ & $0,786^{* *}$ \\
\cline { 2 - 6 } & $\mathrm{p}$ & 0,000 & 0,000 & 0,000 & 0,000 \\
\hline
\end{tabular}

Korelasyon analizi etik lider davranışı ile örgütsel özdeşleşme arasında yüksek, pozitif yönde anlamlı ilişkinin varlığını ortaya koymuştur. (anlamlılık düzeyi: $0,000<0,05)$ Bu ilişkinin düzeyi (r) 0.786 olarak hesaplanmıştır. Örgütsel özdeşleşme ile etik lider davranışı alt boyutları ilişkilerin tespiti için gerçekleştirilen korelasyon analizi sonuçlarına göre sırası ile etik ve adalet boyutu ile orta, pozitif yönde anlamlı $(\mathrm{r}=0,682)$, görevlerin/rollerin açıklı̆̆a kavuşturulması ile arasında orta ve pozitif yönde anlamlı $(\mathrm{r}=0,57)$ ve son olarak güç paylaşımı boyutu ile orta ve pozitif yönde $(\mathrm{r}=0,651)$ anlamlı ilişkiler görülmektedir.

Son olarak örgütsel özdeşleşme ile ÖVD arasında pozitif yönlü, anlamlı ve orta derecede $(0,691)$ bir ilişki görülmektedir.

Tablo 9 Çalışanların Örgütsel Özdeşleşme ile Örgütsel Vatandaşlık Davranışı Düzeyleri Arasındaki İlişki

\begin{tabular}{|c|c|c|c|c|c|c|c|}
\hline & & Özgecilik & Nezaket & $\begin{array}{l}\text { Centilmenlik/ } \\
\text { gönüllülük }\end{array}$ & $\begin{array}{l}\text { Yüksek } \\
\text { Görev } \\
\text { Bilinci }\end{array}$ & $\begin{array}{l}\text { Sivil } \\
\text { Erdem }\end{array}$ & ÖVD \\
\hline $\begin{array}{c}\text { Örgütsel } \\
\text { Özdeşleşme }\end{array}$ & $\mathrm{r}$ & $0.508^{* *}$ & $0.649^{* *}$ & $0.444^{* *}$ & $0.181^{* *}$ & $0.617^{* *}$ & $0,691^{* *}$ \\
\cline { 2 - 7 } & $\mathrm{p}$ & 0,000 & 0,000 & 0,000 & 0,067 & 0,000 & 0,000 \\
\hline \multicolumn{7}{|c|}{ Korelasyon katsay1s1 0,05 derecesinde anlamlıdır $(\mathrm{p}<0,05)$}
\end{tabular}

Örgütsel özdeşleşme nezakete dayalı bilgilendirme, sivil erdem ve özgecilik boyutlarıyla orta dereceli $(0,649 ; 0,617 ; 0,508)$, centilmenlik/gönüllülük ve yüksek görev bilinci boyutlarıyla zayıf ilişkiye sahiptir $(0,444 ; 0,181)$.

Değişkenler arasında var olan ilişkinin yönü ve derecesi korelasyon analizi ile tespit edildikten sonra söz konusu değişkenler arasındaki neden-sonuç ilişkisinin ortaya konulması adına regresyon analizinden yararlanılmıştır. 
Öncelikli olarak etik liderliğin vatandaşlık davranışı üzerindeki etkisinin test edildiği regresyon analizi sonuçları etik liderlik ile ÖVD arasında pozitif yönde ve anlamlı bir etki ortaya koymuştur $(\mathrm{p}<0,05)$. Etik liderlikte bir birim değişim örgütsel vatandaşl1k davranışı üzerinde $\% 70$ değerinde bir artışa sebep olmaktadır. Örgütsel vatandaşlık davranışındaki değişimin \%50'si etik liderlik ile açıklanabilmektedir.

Tablo 10 Etik Liderliğin Örgütsel Vatandaşlık Davranışı Üzerindeki Etkisi

\begin{tabular}{|c|c|c|c|c|c|c|c|c|c|}
\hline & \multicolumn{5}{|c|}{ Katsayı Tablosu } & \multicolumn{2}{|c|}{ Model Özeti } & \multicolumn{2}{|c|}{ ANOVA } \\
\hline $\begin{array}{l}\text { Bağımsız } \\
\text { Değişken }\end{array}$ & B & $\begin{array}{l}\text { Std. } \\
\text { Hata }\end{array}$ & Beta & $\mathrm{T}$ & $\mathrm{P}$ & $\mathrm{R}$ & $\overline{\mathrm{R}^{2}}$ & $\mathrm{~F}$ & $\mathrm{P}$ \\
\hline EL & 574 & ,028 & ,709 & $\begin{array}{l}19,36 \\
5\end{array}$ & 000 & ,709 & ,503 & 426,966 & ,000 \\
\hline Etik ve Adalet & ,357 & , 028 &, 522 & $\begin{array}{l}12,56 \\
1\end{array}$ & ,000 &, 522 & ,272 & 157,769 & ,000 \\
\hline $\begin{array}{l}\text { Görevlerin/Roll } \\
\text { erin Açılılı̆a } \\
\text { Kavuşturulması }\end{array}$ & ,390 & ,023 & ,636 & $\begin{array}{l}16,92 \\
9\end{array}$ & ,000 & ,636 & ,404 & 286,588 & ,000 \\
\hline Güç Paylaşımı & ,369 & ,027 & 559 & $\begin{array}{l}25,09 \\
2\end{array}$ & 000 & 559 & ,312 & 191,437 & 000 \\
\hline
\end{tabular}

Bununla birlikte etik liderliğin örgütsel özdeşleşme üzerinde pozitif yönde ve anlamlı bir etkisi bulunmuştur. $(\mathrm{p}<0,05)$. Etik liderlik üzerinde bir birim artış örgütsel özdeşleşme üzerinde \%78'lik bir artışa neden olmakta; örgütsel özdeşleşme üzerindeki değişimin \%61'i etik liderlik tarafından açıklanabilmektedir.

Tablo 11 Etik Liderliğin Örgütsel Özdeşleşme Üzerindeki Etkisi

\begin{tabular}{|c|c|c|c|c|c|c|c|c|c|}
\hline & \multicolumn{5}{|c|}{ Katsayı Tablosu } & \multicolumn{2}{|c|}{ Model Özeti } & \multicolumn{2}{|c|}{ ANOVA } \\
\hline $\begin{array}{l}\text { Bağımsız } \\
\text { Değisken }\end{array}$ & $\mathrm{B}$ & $\begin{array}{l}\text { Std. } \\
\text { Hata }\end{array}$ & Beta & $\mathrm{T}$ & $\mathrm{P}$ & $\mathrm{R}$ & $\overline{\mathrm{R}^{2}}$ & $\mathrm{~F}$ & $\mathrm{P}$ \\
\hline EL & ,765 & ,029 & ,786 & 10,842 & ,000 & ,786 & ,618 & 683,657 &, 000 \\
\hline $\begin{array}{l}\text { Etik ve } \\
\text { Adalet }\end{array}$ & 561 & ,029 & 682 & 19,138 & ,000 & ,682 & 465 & 366,253 & ,000 \\
\hline $\begin{array}{l}\text { Görevleri } \\
\text { n/Rollerin } \\
\text { Açıklığa } \\
\text { Kavuşturu } \\
\text { lması }\end{array}$ & ,421 & ,029 & ,570 & 14,264 & ,000 & ,570 & ,325 & 203,465 & ,000 \\
\hline $\begin{array}{l}\text { Güç } \\
\text { Paylaşımı }\end{array}$ & ,517 & ,028 & ,651 & 17,632 & ,000 & ,651 & ,424 & 310,905 & ,000 \\
\hline
\end{tabular}

Örgütsel özdeşleşmenin örgütsel vatandaşlık davranışı üzerinde etkisinin tespit edilmesine yönelik yapılan regresyon analiz sonuçlarına göre örgütsel özdeşleşmenin örgütsel vatandaşlık davranışı üzerinde pozitif yönde ve anlamlı bir etkisi bulunmaktadır $(\mathrm{p}<0,05)$. ) Örgütsel özdeşleşme üzerinde bir birim artış ÖVD üzerinde \%69'lik bir artışa neden olmakta; örgütsel özdeşleşme üzerindeki değişimin \%47'si örgütsel özdeşleşme tarafından açıklanabilmektedir. 
D. Palalar Alkan \& F. Ş. Arıkboğa / Etik Liderlik ve Örgütsel Vatandaşlık Davranışı İlişskisinde Örgütsel Özdeşleşmenin Aracllik Etkisi ve Bir Uygulama

Tablo 12 Örgütsel Özdeşleșmenin ÖVD’ye Etkisi

\begin{tabular}{|c|c|c|c|c|c|c|c|c|c|c|}
\hline & & \multicolumn{5}{|c|}{ Katsayı Tablosu } & \multicolumn{2}{|c|}{ Model Özeti } & \multicolumn{2}{|c|}{ ANOVA } \\
\hline $\begin{array}{l}\text { Bağımsı } \\
\mathrm{z} \\
\text { Değişke } \\
\mathrm{n}\end{array}$ & $\begin{array}{l}\text { Bağımlı } \\
\text { Değgişke } \\
n\end{array}$ & B & $\begin{array}{l}\text { Std. } \\
\text { Hata }\end{array}$ & Beta & $\mathrm{T}$ & $\mathrm{P}$ & $\bar{R}$ & $\mathrm{R}^{2}$ & $\mathrm{~F}$ & $\mathrm{P}$ \\
\hline \multirow{6}{*}{$\begin{array}{l}\text { Ö. } \\
\text { Özdeşle } \\
\text { şme }\end{array}$} & ÖVD & ,575 & ,029 & ,691 & $\begin{array}{l}19,64 \\
6\end{array}$ & , 000 & ,691 & ,478 & $\begin{array}{l}385,9 \\
63\end{array}$ & ,000 \\
\hline & $\begin{array}{l}\text { Özgecili } \\
\mathrm{k}\end{array}$ & ,560 & ,046 & ,508 & $\begin{array}{l}12,10 \\
2 \\
\end{array}$ & , 000 & ,508 & ,258 & $\begin{array}{l}146,4 \\
47 \\
\end{array}$ & ,000 \\
\hline & $\begin{array}{l}\text { İleri } \\
\text { Görev } \\
\end{array}$ & , 151 & ,040 & , 181 & 3,780 & ,000 & , 181 & ,033 & $\begin{array}{l}14,29 \\
0\end{array}$ & ,000 \\
\hline & $\begin{array}{l}\text { Centilm } \\
\text { enlik }\end{array}$ & ,437 & ,043 & ,444 & $\begin{array}{l}10,17 \\
7\end{array}$ & , 000 & , 444 & ,197 & $\begin{array}{l}103,5 \\
77\end{array}$ & ,000 \\
\hline & $\begin{array}{l}\text { Sivil } \\
\text { Erdem } \\
\end{array}$ & ,871 & ,054 & ,617 & $\begin{array}{l}16,12 \\
1\end{array}$ & ,000 & ,617 & ,381 & $\begin{array}{l}259,8 \\
72\end{array}$ & ,000 \\
\hline & Nezaket & ,856 & ,049 & 649 & $\begin{array}{l}17,53 \\
7\end{array}$ & ,000 & ,649 & ,422 & $\begin{array}{l}307,5 \\
49\end{array}$ & ,000 \\
\hline
\end{tabular}

Yapılan regresyon analizleri sonucunda etik liderliğin örgütsel vatandaşlık davranışı ve örgütsel özdeşleşme üzerinde; örgütsel özdeşleşmenin de örgütsel vatandaşlık davranışı üzerindeki etkisi istatistiksel olarak anlamlı sonuçlar ortaya Çalışmanın temel sorusu etik liderliğin örgütsel vatandaşlık davranışı üzerindeki etkisinde örgütsel özdeşleşmenin aracılık etkisi olup olmadığıdır. Bu çerçevede yapılan regresyon analizinde etik liderliğin örgütsel vatandaşlık üzerindeki etkisi test edildikten sonra etik liderlik ile örgütsel özdeşleşmenin karşıl1klı etkileşiminin örgütsel vatandaşlık davranışı üzerindeki etkisi araştırılmıştır. Bu doğrultuda hiyerarşik regresyon analizinden yararlanılacaktır.

$\mathrm{Bu}$ çerçevede, ilk aşamada bağımsız değişken olan etik liderliğin bağımlı değişken olan örgütsel vatandaşlık davranışı üzerinde anlamlı etkisi araştırılmıştır. İkinci aşamada ise bağımsız değişken olan etik lider davranışlarının aracı değişken olan örgütsel özdeşleşme üzerindeki etkisi analiz edilmiştir. Üçüncü aşamada ise bağımsız değişken olan etik liderlik ile aracı değişken olan örgütsel özdeşleşmenin karşılıklı etkileşiminin bağımlı değişken olan örgütsel vatandaşlık davranışı üzerindeki etkisi araştırılmıştır.

$\mathrm{Bu}$ amaçla Model 1'de öncelikli olarak etik liderliğin örgütsel vatandaşlık davranışı üzerindeki anlamlı etkisi saptanmıştır $(\mathrm{p}<0,05)$. Hiyerarşik regresyonun ikinci aşamasında ise bağımsız değişken olan etik liderliğin aracı değişken olan örgütsel özdeşleşme üzerindeki etkisi araştırılmıştır. Regresyonun son aşamasında ise bağımsız değişken olan etik liderlik ile aracı değişken örgütsel özdeşleşmenin aynı anda analize dâhil edilerek bağımlı değişken üzerinde anlamlı ancak azalan ilişkisi gözlemlenmiştir. Bu doğrultuda etik liderliğin toplam etkisi aşağıdaki gibi hesaplanmaktadir;

$$
0,574=0,352+(0,765 * 0,291)
$$


Tablo 13. Hiyerarşik Regresyon Analizi Sonuçları

\begin{tabular}{|c|c|c|c|c|c|c|c|c|c|}
\hline \multirow{2}{*}{$\begin{array}{l} \\
\text { Bağımsız } \\
\text { Değişken }\end{array}$} & \multicolumn{3}{|c|}{$\begin{array}{l}\text { Örgütsel Vatandaşlık } \\
\text { Davranışı }\end{array}$} & \multicolumn{3}{|c|}{ Örgütsel Özdeşleşme } & \multicolumn{3}{|c|}{$\begin{array}{l}\text { Örgütsel Vatandaşlık } \\
\text { Davranışı }\end{array}$} \\
\hline & B & $\mathbf{t}$ & $\mathbf{p}$ & B & $\mathbf{t}$ & $\mathbf{p}$ & 及 & $\mathbf{t}$ & $\mathbf{p}$ \\
\hline Sabit & $\begin{array}{l}1,87 \\
9\end{array}$ & $\begin{array}{l}19,36 \\
5\end{array}$ & $\begin{array}{l}\text { 0,000* } \\
*\end{array}$ & $\begin{array}{l}1,10 \\
8\end{array}$ & $\begin{array}{l}10,84 \\
2\end{array}$ & $\begin{array}{l}\mathbf{0 , 0 0 0} * \\
*\end{array}$ & $\begin{array}{l}1,55 \\
7\end{array}$ & $\begin{array}{l}14,88 \\
7\end{array}$ & $\begin{array}{l}\mathbf{0 , 0 0 0} * \\
*\end{array}$ \\
\hline Etik Liderlik & $\begin{array}{l}0,57 \\
4\end{array}$ & $\begin{array}{l}20,66 \\
3\end{array}$ & $\begin{array}{l}\text { 0,000* } \\
*\end{array}$ & $\begin{array}{l}0,76 \\
5\end{array}$ & $\begin{array}{l}26,14 \\
7\end{array}$ & $\begin{array}{l}\mathbf{0 , 0 0 0 *} \\
*\end{array}$ & $\begin{array}{l}0,35 \\
2\end{array}$ & 8,200 & $\begin{array}{l}\mathbf{0 , 0 0 0 *} \\
*\end{array}$ \\
\hline $\begin{array}{l}\text { Örgütsel } \\
\text { Özdeşleşme }\end{array}$ & - & - & - & - & - & - & $\begin{array}{l}0,29 \\
1\end{array}$ & 6,607 & $\begin{array}{l}\mathbf{0 , 0 0 0 *} \\
*\end{array}$ \\
\hline $\mathbf{F}$ & \multicolumn{3}{|c|}{426,966} & \multicolumn{3}{|c|}{683,657} & \multicolumn{3}{|c|}{256,889} \\
\hline Model (p) & \multicolumn{3}{|c|}{$0,000 * *$} & \multicolumn{3}{|c|}{$0,000 * *$} & \multicolumn{3}{|c|}{$0,000 * *$} \\
\hline $\mathbf{R}^{2}$ & \multicolumn{3}{|c|}{0,502} & \multicolumn{3}{|c|}{0,617} & \multicolumn{3}{|c|}{0,547} \\
\hline
\end{tabular}

Tablo 13'te belirtilen etik liderliğin örgütsel vatandaşlık davranışı üzerine etkisinde, örgütsel özdeşleşmenin aracılık rolüne ilişkin regresyon analizi incelendiğinde örgütsel özdeşleşmenin kısmi aracılık etkisi ispatlanmıştır.

\section{SONUÇ}

Günümüz iş dünyasında uzun dönemli işletme başarısı ve etkinliği liderin güçlü bir vizyona sahip olması ve bu vizyonun izleyiciler tarafından benimsenmesi ile mümkün olabilmektedir. Paylaşılan bir vizyon ise liderin bütünlük, doğruluk, eşitlik ve güvenilirlik gibi evrensel ilkeler 1şığında liderlik sürecini ortaya koyması ile geçerlilik kazanmaktadır. Bunun yanı sıra farklı etnik grup ve kuşakların iç içe olduğu günümüz işletmeleri bu farklılıkların yönetilmesinde etik değerlere vurgu yapan bir liderliğe gereksinim duymaktadır. $\mathrm{Bu}$ çerçevede etik liderlik üzerine ortaya konulan çalışmalarda, söz konusu liderlik, etik ve adalet gibi değerleri önceleyen, iki yönlü iletişim ile örgütte etik davranışları teşvik eden ve karar alma gücünü paylaşan bir liderlik yaklaşımı olarak nitelendirilmektedir. Ancak bu noktada etik liderlik ile güncel liderlik yaklaşımları arasında belirgin farklar olduğu gözlemlenmektedir. Bu farklılıkların ortak noktası ise etik liderlik sürecinde etik değerlerin olumlu rol modelleme ile izleyiciler tarafından içselleştirilmesi sağlanarak; örgütte etik farkındalığın yaratılması üzerindeki aktif rolüdür. Ayrıca etik kavramı etik liderlik yaklaşımında normatif yapısından kurtarılarak, sadece lidere atfedilen özellikler olmaktan çok liderlik sürecine rehberlik eden ilkeler olarak değerlendirilmektedir.

Etik liderin öncelikli rolü gerekli iletişim becerileri kullanarak çalışanların ahlaki gelişimlerine katkıda bulunmak; söz konusu değerlerin çalışanlar tarafından içselleştirilmesi ve paylaşılan bir etik kültürün yaratılmasını sağlamaktır. Özellikle daha önce de ifade edildiği gibi günümüz işletmelerin farklı kuşak, etnik köken ve kültürlere sahip olması beşeri sermayenin yönetimini daha karmaşık bir hale dönüştürmektedir. Bununla birlikte iş dünyasında son yıllarda etkileri küresel çapta hissedilen krizlerin önemli bir nedeni de etik dişı yönetimin varlığıdır. Örneğin, 2008 finansal krizinin önemli sebeplerinden biri 
bankacılık sektöründe yüksek riskli kredilendirme politikalarının yaygın bir şekilde yönetim tarafindan benimsenerek uygulanmasıdır. Bu nedenle bireylerin eylemleri ve eylemlerinin sonuçlarına rehberlik eden etik ilkeler liderlik sürecinde önemli bir rol oynamaktadır. Etik lider, çalışanların ahlaki gelişimine olumlu yönde etki ederek; etik farkındalığın yaratılması konusunda izleyicilere rol model olmaktadır. Bununla birlikte etik liderliğin çalışan odaklı yaklaşımı bireylerin işe yönelik olumlu tutum ve davranışlar sergilemelerine yol açmaktadır.

Liderlik çalışmalarında insan ilişkileri güçlü, etik davranışlar sergileyen, gücünü ve otoritesini tüm paydaş çıkarlarının dengelenmesi yönünde kullanan yöneticilerin önemi gün geçtikçe daha çok anlaşılmaktadır. Bu doğrultuda dürüstlük, bütünlük, tarafsızlık ve güvenilirlik gibi değerler üzerine temellenen etik lider davranışları çalışanların işe yönelik davranış ve tutumlarına etki etmektedir. Özellikle etik liderin iki yönlü iletişim ve güvenilirlik gibi karakteristik nitelikleri örgütte güven duygusunu arttırarak bireylerin örgütleri ile özdeşleşmelerine yol açmaktadır. Örgütleri ile özdeşleşen bireyler ise örgütle bir olma ya da aidiyetlik duygusu ile davranışlarını şekillendirmektedir. Bununla birlikte örgüt ile çalışan arasında değerler bazında bu benzeşim "biz" algısının oluşumuna etki ederek; çalışanın iş tanımı kapsamında yer almayan ve örgütsel vatandaşlık davranışı (ÖVD) olarak nitelendirilen gönüllülük esasına dayanan olumlu davranışlar ortaya koymasına neden olmaktadır. Bu davranışlar, çalışan verimliliği ile yönetsel etkinliğin arttırılmasında; gruplar arası işbirliği ve koordinasyonun sağlanmasında ve işgücü devir hızının azaltılmasında önemli bir etkiye sahiptir. Etik liderlik üzerine yapılan diğer çalışmalarla etik liderliğin ÖVD ile ilişkisine aracılık eden örgütsel adalet, güven, bağlllık ve iş tatmini gibi faktörlerin varlığı literatürde tartışılmaktadır. Bu nedenle çalışmada örgütsel özdeşleşmenin etik liderlik ve ÖVD ilişkisinde kısmi aracılık etkisi öngörülmüş; bu etki bankacılık sektöründe gerçekleştirilen araştırma sonuçları ile ispatlanmıştır.

Bankacılık sektörünün çalışmada tercih edilmesinin çeşitli nedenleri vardır. Öncelikle bankacılık sektöründe yaşanabilecek finansal krizlerin genel ekonomik sistem üzerinde kuvvetli bir etkisi bulunmaktadır. Buna ek olarak para toplama ve kredi açma özelliği bankacılık sektöründe güven konusunun önemini vurgulamaktadır. Bankalar mevduat hizmeti ile kişi ve firmalara kredi sağlamakta; piyasaya sunulan kredi imkânları ile yapılacak yatırımların yönünü belirlemektedirler. Bir bankanın itibarı yasa ve mevzuatlara uyumun yanı sıra tüm paydaşları ile ilişkilerinde dürüstlük, adalet, güvenilirlik ve sorumluluk gibi etik değerlere bağlılığını zorunlu kılmaktadır. Bankacılık kaynaklı krizlerin en temel sebeplerinden biri ise etik dışı yönetim şeklinde ifade edilmektedir. Bu nedenle bankacılık sisteminin düzenli işleyişi iş sürecinin her bir noktasında etik değerlerin benimsetilmesi ve ortak sorumluluk duygusunun yaratılmasını gerektirmektedir. Bu çerçevede etik lider, olumlu rol modelleme ile sahip olduğu etik değerleri örgütün değerlerine dönüştüren; gücünü ve yetkisini çalışanların bu değerleri içselleştirilmesi adına kullanan ve örgütte etik farkındalığın oluşumunu sağlayan bir liderlik sürecidir. Etik liderin bu özellikleri göz önünde 
bulundurulduğunda bankacılık sektöründe liderlerin, etik temelli yönetim sergilemeleriyle bankacılık sistemine olan güveni arttıracağı, sektörün sağlıklı işleyişi üzerinde olumlu etkiye sahip olacağ 1 düşünülmektedir. Araştırma bulgularında çalışanların algıladıkları etik liderlik tarzının yüksek çıkması da bu öngörüyü desteklemektedir. Araştırma sonuçları bankacılık sektörü çalışanlarının yüksek düzeyde örgütsel özdeşleşme ve örgütsel vatandaşlık davranış1 sergilemelerine işaret etmektedir. Böylelikle çalışma bulguları örgütsel özdeşleşmenin ÖVD üzerindeki etkisini ortaya koyan önceki çalışmaları desteklemektedir.

Araştırma bulguları etik liderliğin örgütsel özdeşleşme üzerindeki etkisini ortaya koymaktadır. Ayrıca etik liderliğin etik ve adalet, görevlerin/rollerin açıklığa kavuşturulması ile güç paylaşımı boyutlarının da çalışanların kurumları ile özdeşleşmelerine yol açtı̆̆ toplanan veriler ile saptanmıştır. Böylelikle bankacılık sektöründe, farklılaşan müşteri ihtiyaçlarını karşılama yarışında ortak sorumluluk ve görev bilincinin yaratılmasını önceleyen etik liderlik, güven sağlayıcı bir unsur olmasının yanı sıra sektördeki haksız rekabetin engellenmesinde de ön plana çıkmaktadır. Çalışmanın temel hipotezi olan etik liderliğin örgütsel vatandaşlık davranışı üzerindeki etkisinde örgütsel özdeşleşmenin aracılık etkisi de çalışma bulguları ile ispatlanmıştır. Bu sonuç, örgüt amaçları ile birey amaçlarının bütünleşmemesi durumunda etik liderliğin örgütsel vatandaşlık davranışı üzerindeki etkisini azalttığı şeklinde değerlendirilebilir. Bu çalışma sonucunda ortaya konulan etik liderlik, ÖVD ve örgütsel özdeşleşme arasındaki ilişkinin yanı sıra etik liderliğin ÖVD üzerindeki etkisinde örgütsel özdeşleşmenin kısmi aracılığının bankacılık sektöründen elde edilen veriler ile ispatlanması, etik liderlik çalışmalarına katkı sağlamıştır. Çalışmada özellikle bankacılık sektörü liderlerinin liderlik sürecine etki eden unsurların ve aracı değişkenlerin belirlenmesine yönelik bulgular sunulmuştur. Araştırmanın farklı sektörlerde geçerliliğinin sağlanabilmesi konusunda çalışmanın hem Türkiye'de bankacılıktan farklı sektörlerde, hem de farklı özelliklere sahip örgüt koşullarında test edilmesi gerekmektedir.

\section{KAYNAKÇA}

Alkan, Deniz Palalar. (2015). Etik Liderlik Ölçeğinin Türkçe Formunun Güvenilirlik Ve Geçerlilik Çalışması. Erciyes Üniversitesi Sosyal Bilimler Enstitüsü Dergisi, 38(1), 109-121.

Bell, S.J., Mengüç, Bulent. (2002). The employee-organization relationship, organizational citizenship behaviors, and superior service quality. Journal of Retailing, 78(2), 131-146.

Bergami, Massimo, Bagozzi, Richard P. (1996) Organizational Identification: Conceptualization Measurement and Nomological Validity, University of Michigan School of Business Administration Working Paper, Issue 9608 (10), 1996, 555-577.

Brown, Michael E., Trevino, Linda K., Harrison, David A. (2005). Ethical Leadership: A Social Learning Perspective For Construct Development And Testing. Organizational Behavior and Human Decision Processes, 97(1),117-134.

Christ, Oliver, van Dick, Rolf, Wagner, Ulrich, Stellmacher, Jost. (2003). When teachers go the extra mile: Foci of organisational identification as determinants of different forms of organisational citizenship behavior among schoolteachers. British Journal of Educational Psychology, 73(1), 329-341. 
D. Palalar Alkan \& F. Ş. Arıkboğa / Etik Liderlik ve Örgütsel Vatandaşlık Davranışı İlişkisinde Örgütsel Özdeşleşmenin Aracılık Etkisi ve Bir Uygulama

Dukerich, Janet M., Golden, Brian R., Shortell, Stephen M.(2002) Beauty Is in the Eye of the Beholder: The Impact of Organizational Identification, Identity, and Image on the Cooperative Behaviors of Physicians, Administrative Science Quarterly, 48(1), 507-533.

Feather,N.T., Rauter, Katrin A. (2004). Organizational Citizenship Behaviours In Relation To Job Status, Job Insecurity, Organizational Commitment and Identification, Job Satisfaction and Work Values. Journal of Organizational Psychology, 77(1), p.90-91.

Hodgetts, Richard M., Luthans, Fred (2003). International Management, Culture, Strategy and Behavior, NY: McGraw Hill//rwin.

Humme, Virginia, van Laar, Felice. (2008) The Relationship Between Ethical Leadership and Organizational Citizenship Behavior. University of Amsterdam.

İşbaşı, Jale Ö. (2000). Örgütsel Vatandaşlık Davranış1: Farklı Ölçeklerin Uygulanabilirliğine İlişkin Bir Çalışma. 8. Ulusal Yönetim ve Organizasyon Kongresi, Erciyes Üniversitesi, 359-372.

Kalaycı, Şeref. (2008). SPSS Uygulamalı Çok Değişkenli İstatistik Teknikleri, 3.basım, Ankara: Asil Yayın Dağıtım.

Karabey, Canan Nur, İşcan, Ömer Faruk. (2007). Örgütsel Özdeşleşme, Örgütsel İmaj Ve Örgütsel Vatandaşlık Davranışı İlişkisi: Bir Uygulama. Atatürk Üniversitesi İ̈BF Dergisi, 21(2), 231243.

Mael, Fred, Ashforth, Blake E.(1992). Alumni and Their Alma Mater: A Partial Test of The Reformulated Model of Organizational Identification. Journal of Organizational Behavior, 13(1), 103-123.

Mayer, David M., Kuenzi, Maribeth, Greenbaum, Bardes, Rebecca, Salvador Mary Rommes. (2009). How low does ethical leadership flow? Test of a trickle- down model. Organizational Behavior and Human Decision Processes, 108(1), 1-13.

Menteş, Ahmet. (2008). Kurumsal Yönetişim Etkinlik Ölçüm Aracı Olarak Tepe Yöneticisi Değişimi: Türkiye Uygulaması. (Yayınlanmamış doktora tezi). İstanbul Üniversitesi Sosyal Bilimler Enstitüsü, İstanbul.

Organ, Dennis W. (1988) The Good Soldier Syndrome, MA: Lexington Books Publishing.

Organ, Dennis W., Podsakoff, Philip M. Scott, MacKenzie B. (2006) Organizational Citizenship Behavior: Its Nature And Antecedents and Consequences, CA: Sage Publications.

Orhunbilge, Neyran. (1997). Örnekleme Yöntemleri ve Hipotez Testleri. İstanbul Üniversitesi İşletme Fakültesi Yayınları, Yayın No: 270.

Özkalp, Enver. (2003) Örgütsel Davranış, Eskişehir: T.C. Anadolu Üniversitesi Açıköğretim Fakültesi Yayınları.

Piccolo, Ronald F., Greenbaum, Rebecca, den Hartog, Deanne N., Folger, Robert. (2010) The relationship Between Ethical Leadership and Core Job Characteristics. Journal of Organizational Behavior. 31(2), 259-278.

Podsakoff, Philip M., Ahearne, Michael, MacKenzie, Scott B. (1997) Organizational Citizenship Behavior and the Quantity and Quality of Work Group Performance. Journal of Applied Psychology, 82(2), 262-270.

Podsakoff, Philip M., MacKenzie, Scott B. (1997). Impact Of Organizational Citizenship Behavior On Organizational Performance: A Review and Suggestions For Future Research, Human Performance, 10(2), 131-151.

Podsakoff, P. M., MacKenzie, S. B., Moorman, R. H., \& Fetter, R. (1990). “Transformational leader behaviours and their effects on followers' trust in leader, satisfaction, and organizational citizenship behaviours. Leadership Quarterly, 1(2), 107-142.

Podsakoff, P. M., MacKenzie, S. B., Paine, J. B., \& Bachrach, D. G. (2000). Organizational citizenship behaviours: A critical review of the theoretical and empirical literature and suggestions for future research. Journal of Management, 26(3), 513-563.

Ruiz-Palomino, Pablo, Ruiz-Amaya, Carmen, Knörr, Helena. (2011) Employee Organizational Citizenship Behavior: The Direct and Indirect Impact of Ethical Leadership, Canadian Journal of Administrative Sciences. 17(3), 244-258.

Toor, Shamas-ur-Rehman, Ofori, George. (2009) Ethical Leadership: Examining the Relationships with Full Range Leadership Model, Employee Outcomes, and Organizational Culture. Journal of Business Ethics, 90(1),.533-547. 
Turan, Zübeyir. (2011). Finansal Piyasalar ve Küreselleşme. Mevzuat Dergisi, 14 (162),1-11.

Türkiye Bankalar Birliği Banka ve Sektör Bilgileri. (2015). http://www.tbb.org. tr/modules/bankabilgileri/banka_Listesi.asp?tarih=05/12/20154.

Türkiye Bankalar Birliği Personel ve Şube Sayıları. (2015). http://www.tbb.org. tr/tr/banka-vesektor-bilgileri/istatistiki-raporlar/mart--2014---banka,-sube-ve-personel-bilgileri-/2411.

van Dick, Rolf, Johannes Ullrich, Patrick A. Tissington, "Working Under Black Cloud: How To Sustain Organizational Identification After A Merger", British Journal of Management, V. XVII, No.1, 2006, pp. 75-76.

Vondey, Michelle. (2010). The Relationships among Servant Leadership, Organizational Citizenship Behavior, Person Organization Fit, and Organizational Identification. International Journal of Leadership Studies, 11(1), 22-24.

\section{SUMMARY}

With the effect of globalization, along with the developments in information technology, human creativity is catalyzator for organization success. Thus it is vital to reexamine the role of leaders in the perspective of motivating employees to sustain long term organizational membership. The increased importance of social and economical responsibilities of businesses to all stakeholders creates a holistic approach to governance also sets the stage for creation of human oriented leadership styles. For this reason it is important to examine the influence of ethical leadership whose primary objective is the creation of ethical awareness by monitoring and managing with the guidance of ethical values.

Within the scope of this study we have examined brief review on ethical leadership concept along with organizational citizenship behavior and organizational identification. The research was supported by data gathered from banking sector since its impact on the society is at large in terms of national economical development. 